\title{
Oral Lichen Planus-A Brief Review on Treatment Modalities
}

\author{
${ }^{1}$ Ketki J Shirke, ${ }^{2}$ Jigna Pathak, ${ }^{3}$ Niharika Swain, ${ }^{4}$ Shilpa Patel, ${ }^{5}$ Tanvi Patel, ${ }^{6}$ Mitesh N Jain
}

\begin{abstract}
Lichen planus is an autoimmune-mediated chronic inflammatory disease of unknown etiology, but studies have reported the role of cytotoxic $T$ cells responsible for the disruption of basal keratinocytes and also causing the clinical symptoms. It is commonly seen in adults, with rare occurrence in children. It clinically manifests on the skin and oral mucosa, with skin lesions healing faster than the oral lesions. To obtain a diagnosis, a complete history and characteristic clinical features are usually sufficient for diagnosis, but there are certain other lesions like lichenoid reaction, contact sensitivity, white sponge nevus, pemphigoid and lupus erythematosus that show similar clinical characteristics, hence the need for histopathological evaluation using standard criteria given by Krutchkoff or World Health Organization (WHO). The treatment administered is always for eliminating symptoms and discomfort of the patients. A variety of pharmacological and natural alternatives have been used, along with frequent follow up visits in case of a tropic and erosive lichen planus. The purpose of this paper is to review the current trends in the management of oral lichen planus.
\end{abstract}

Keywords: Lichen planus, Management, Update.

How to cite this article: Shirke KJ, Pathak J, Swain N, Patel S, Patel T, Jain M. Oral Lichen Planus-A Brief Review on Treatment Modalities. J Contemp Dent 2018;8(3):137-143.

\section{Source of support: Nil}

Conflict of interest: None

\section{INTRODUCTION}

Oral lichen planus (OLP) is a chronic mucocutaneous disease of multifactorial etiologies with Wilson first describing it in 1869. It was suggested by authors to an autoimmune disease triggered by antigens in the form of extrinsic or intrinsic factors that activate the lymphocytes and releases cytokines that are directed against the basilar keratinocytes leading to their apoptosis. It was seen to affect $0.5-1 \%$ of the worldwide population and

\footnotetext{
${ }^{1,5,6}$ Postgraduate Student, ${ }^{2}$ Professor, ${ }^{3}$ Lecturer, ${ }^{4}$ Professor and HOD

${ }^{1-6}$ Department of Oral Pathology and Microbiology, Mahatma Gandhi Mission Dental College and Hospital, Navi Mumbai, Maharashtra, India

Corresponding Author: Ketki J Shirke, Postgraduate Student, Department of Oral Pathology and Microbiology. Mahatma Gandhi Mission Dental College and Hospital, Navi Mumbai, Maharashtra, India, Mobile: +918149235625, e-mail: shirkeketki09@gmail.com
}

$0.1-1.5 \%$ prevalence in India. ${ }^{1}$ The condition affects the cutaneous or mucosal areas or both, where $50 \%$ of individuals with cutaneous lichen planus had oral mucosal lesions, and about $25 \%$ presented with, oral mucosal lesions alone. ${ }^{2}$ It was seen most commonly in adults and had a female prediliction. ${ }^{3}$

An OLP commonly affects the buccal mucosa, gingiva, and the tongue, with an uncommon presentation on the palate. ${ }^{4}$ It is usually seen as multiple lesions, bilaterally present in the mouth persisting for a longer duration of up to 25 years in comparison to the cutaneous counterpart. ${ }^{5,6}$ It shows a chronic course having periods of dormancy and flare-ups with spontaneous remissions rarely seen.?

Andreasen ${ }^{2}$ divided oral lichen planus into six clinical types: reticular, plaque-like, papular, erosive, bullous, and atrophic types where erosive and atrophic types caused discomfort and painful symptoms. On clinical examination, in the absence of the reticular type which is easily identifiable, the other types of oral lichen planus requires histopathological evaluation for a definite diagnosis. This is done using WHO criteria (2003) for diagnosis of OLP, that includes clinical criteria's, histopathological criteria's and final differentiation of lichen planus from lichenoid lesions. ${ }^{8}$

An OLP is a disease with a potential for malignant transformation. It has been noted that the rate of malignant transformation has decreased from 5.9\% in 1924 to $0.5-1.1 \%$ in $2017 .^{9}$ However, this possibility may be reduced by patient counseling, consumption of a healthy diet and avoiding carcinogens. ${ }^{10}$ The standard proto$\mathrm{col}$ for the management of oral lichen planus includes symptomatic relief with no complete cure. Various alternatives have been applied in the management which suggests the inadequacy of any single drug to provide relief. The present article hereby provides an overview of different treatment modalities in the management and the advancements made in obtaining control over the symptoms of OLP.

The OLP could be symptomatic (erosive, atrophic and bullous types) or asymptomatic (reticular or plaque types). The symptomatic oral lichen planus can cause a burning sensation, severe pain, inability to speak and swallow, which is seen to be the chief complaint of the patient requiring symptomatic relief ${ }^{11}$ while the asymptomatic forms do not require pharmacological interven- 
Flow Chart 1: Treatment protocol for oral lichen planus

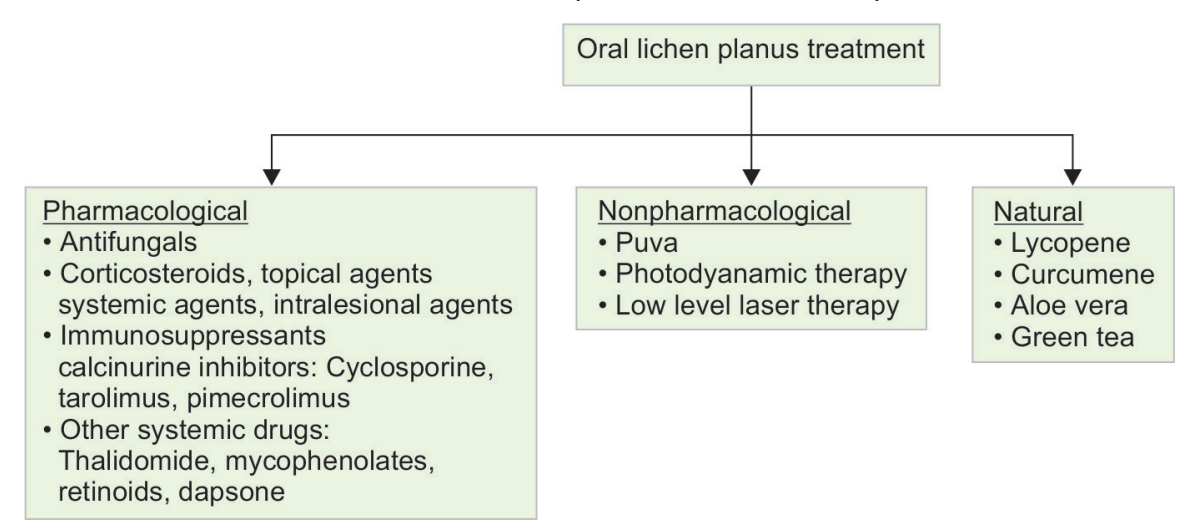

Table 1: List of antifungals used in the treatment of oral lichen planus

\begin{tabular}{ll}
\hline Drugs & Dose \\
\hline Clobetasol & $0.025 \%, 0.05 \%$ \\
Miconazole & $2 \%$ \\
Amphoterecin B & $0.1 \%$ \\
Tab Griseofulvin & $500 \mathrm{mg} /$ day for 6 months \\
\hline
\end{tabular}

tion. The treatment plan is formulated according to the psychological state, medical history of drug interactions and drug compliance of the patient. ${ }^{12}$ The most accepted treatment protocol for OLP is depicted in Flow Chart 1.

The treatment plan consisting of pharmacological therapy includes antifungals (Table 1), corticosteroids (Table 2), immunosuppressant's (Table 3) and other systemic drugs (Table 4), whereas, the other treatment modalities include nonpharmacological therapy (Table 5), natural alternatives (Table 6) and surgery.

\section{Pharmacological Therapy}

\section{Antifungals}

Candida albicans is seen to be present in $37 \%$ of the OLP lesions (superimposed candidal infections) which exacerbates it and produces symptoms. This could be because, in erosive lesions on the gingiva or oral mucosa, maintenance of oral hygiene is difficult leading to fungal infections. Another reason can be the prolonged use of corticosteroids, which leads to decrease in the immune mechanism of the mucosa and also reduces the salivary flow, leading to altered microflora and hence enhanced candida growth in the oral cavity. ${ }^{13}$ Infection and inflammation caused by Candida was seen to show changes in the epithelium which was histopathologically misdiagnosed as dysplasia. ${ }^{14}$ Hence an antifungal therapy is advised (Table 1) as it can change the erosive form of OLP into reticular forms. ${ }^{15}$

The antifungal griseofulvin was used by Sehgal in 1972 and was found to be useful in the management of oral LP, unlike others who found no improvements in the lesion. ${ }^{16}$ Symptomatic relief was reported on using other antifungals like amphotericin B, azoles and nystatin. The use of topical miconazole was also found to be an effective antifungal against candidal superinfections during topical steroid therapy. ${ }^{17}$ The use of clobetasol showed greater chances of oral fungal infection than any other steroid therapy; hence an accompanying antifungal (clotrimazole)could be used as it produced greater symptom relief than any other antifungal. ${ }^{18}$

\section{Corticosteroids}

Corticosetroids in the form of topical agents, intralesional injections and systemic drugs is considered to be the mainstay of the treatment of oral lichen planus. The details about the drugs used and its mechanism of action with adverse effects is mentioned in Table 2.

\section{Immunosuppressans and Other Systemic Drugs}

Immunosuppressant's are the agents used to suppress the immune mechanism that targets and damages the host. The details of the immunosuppressant's as well as the other systemic drugs that are used in the management of oral lichen planus along with their mechanism of action, dosage and adverse effects is mentioned in Tables 3 and 4 .

\section{Nonpharmacological Therapy}

Several nonpharmacological modalities have been used for the treatment of recalcitrant oral lichen planus have been discussed in Table 5.

\section{Natural Alternatives}

The current drug treatments seem to be only palliative and have also shown to have various adverse effects, hence, valuable natural therapies have been inculcated for effective treatment of oral lichen planus. The details of the natural agents used with their mechanism of action and dosages have been discussed in Table 6 . 
Oral Lichen Planus-A Brief Review on Treatment Modalities

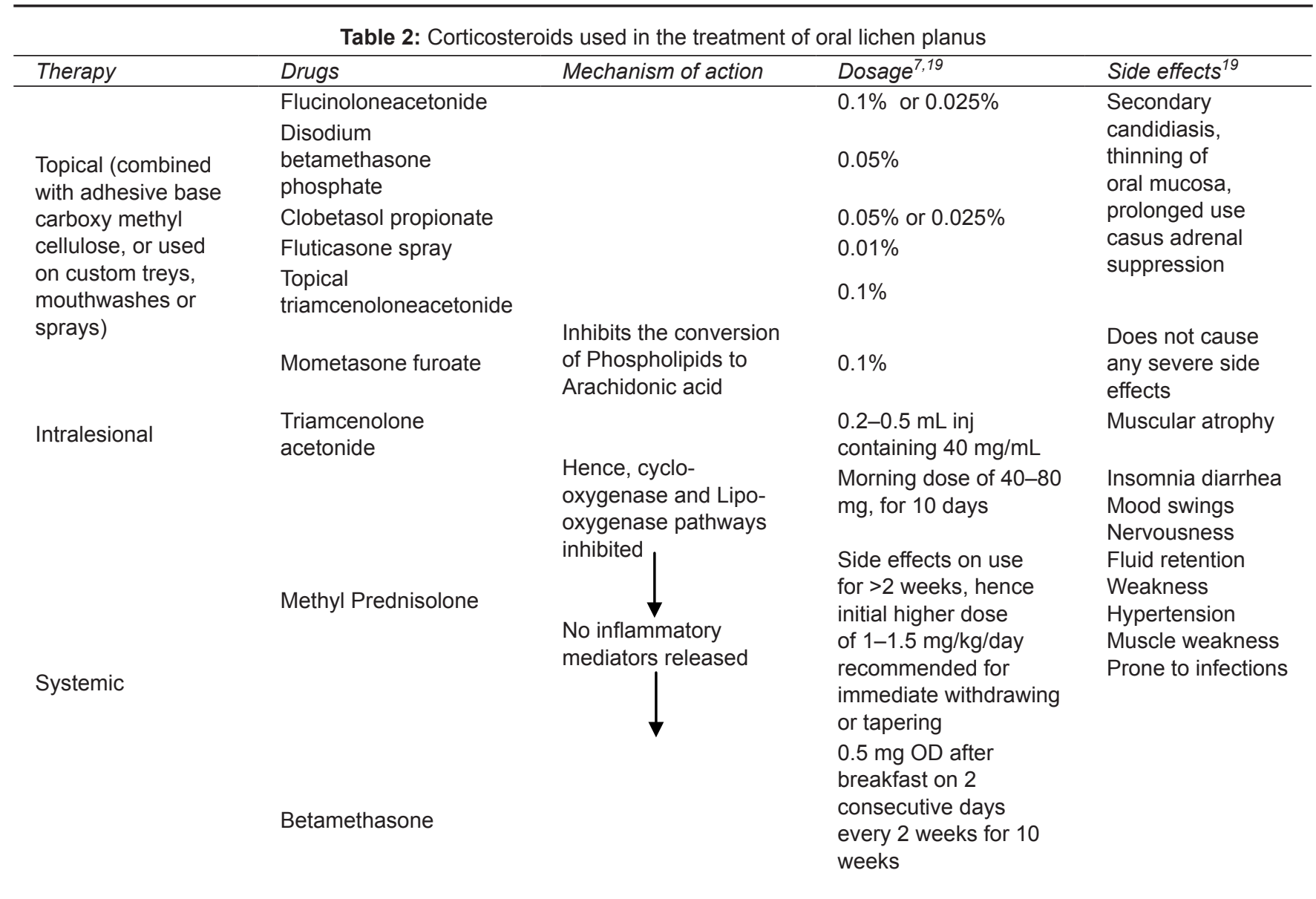

Mostafa and Zakaria in 2018 assessed the therapeutic advantage of the use of topical corticosteroids in combination with ozone (60\% for 1 min in each session twice a week for four weeks), they found that there was considerable decrease in the discomfort in symptomatic patients and there as also decrease in the Candida growth due to bactericidal, fungicidal and virucidal properties of ozone ${ }^{20}$

\section{Surgery}

Surgical excision of the lesional tissue should not be considered as the primary treatment modality because lichen planus is an inflammatory disease which will reoccur. Its application for multicentric lesions, erosive and atopic oral lichen planus was not advisable as the surface epithelium is eroded. Laser ablation using carbon dioxide and cryosurgery is considered in erosive oral lichen planus resistant to most treatment modalities. Surgery is advisable in plaque type of lichen planus as the superficial layer of the lesion can easily be removed. Localized erosive oral lichen planus lesions also were seen showing complete eradication of symptoms following treatment with a free gingival graft after a follow-up of 3.5 years.

Table 3: Immunosuppressants used in oral lichen planus

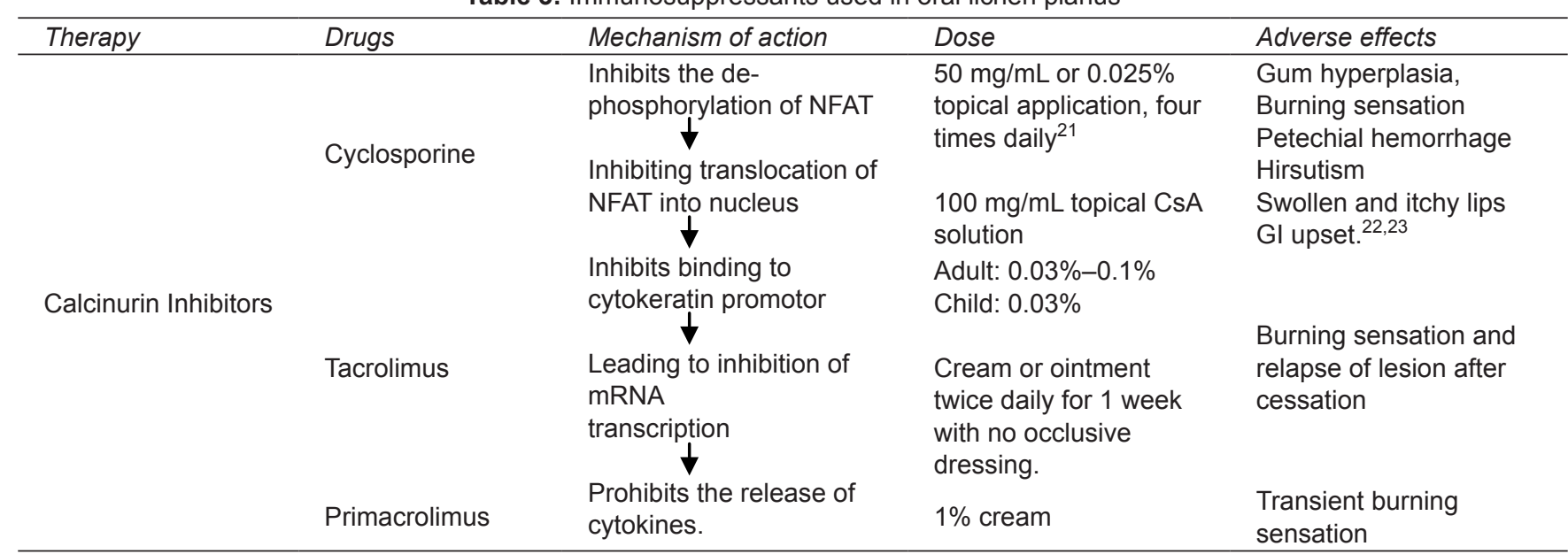

(NFAT: Nuclear Factor of Activated T-cells, CsA: Cyclosporin A)

Systemic calcinurin inhibitors are rarely used as it causes gingival hyperplasia, HTN, DM, tremors, nephrotoxicity, nausea, seizures and dyslipidemia 
Table 4: Other drugs used in oral lichen planus

\begin{tabular}{|c|c|c|c|}
\hline Therapy & Mechanism of action & Dose & Adverse effect \\
\hline Thalidomide & $\begin{array}{l}\text { Reduces TNF- } \alpha \text { production. } \\
\text { Increases activity of suppressor } \\
\text { T-cells } \\
\text { Inhibits angiogenesis. }\end{array}$ & $\begin{array}{l}\text { Initial dose of } 50 \mathrm{mg} / \text { day progressively } \\
\text { increased to } 200 \mathrm{mg} / \text { day over } 3 \text { months. } \\
\text { If adverse effects noted dose was decreased to } \\
100 \mathrm{mg} / \text { day. }\end{array}$ & $\begin{array}{l}\text { Dizziness } \\
\text { Edema } \\
\text { Rashes }\end{array}$ \\
\hline $\begin{array}{l}\text { Mycophenol- } \\
\text { ates } \\
\text { (used in cases } \\
\text { resistant to } \\
\text { topical steroids) }\end{array}$ & $\begin{array}{l}\text { Suppresses dendritic cell } \\
\text { maturation. } \\
\text { Formation of antibodies and } \\
\text { inhibits lymphocyte proliferation. }{ }^{24}\end{array}$ & $\begin{array}{l}200 \mathrm{mg} / \text { day in combination with calcinurine } \\
\text { inhibitors } 150 \mathrm{mg} / \text { day followed by tapering the } \\
\text { dose and finally withdrawing it. }\end{array}$ & $\begin{array}{l}\text { GI disturbance } \\
\text { headache } \\
\text { Tiredness } \\
\text { myelosuppression } \\
\text { embryopathy. }{ }^{25}\end{array}$ \\
\hline Retinoids: & $\begin{array}{l}\text { They stimulate macrophage } \\
\text { activation and antibody dependent } \\
\text { cell mediated cytotoxicity. }\end{array}$ & $\begin{array}{l}\text { Systemic: } 10,000 \mathrm{IU} \text { retinoids. } \\
\text { Etretinate- } 0.6 \mathrm{mg} / \mathrm{kg} / \mathrm{day} \text { for } 2 \mathrm{months} \text { followed } \\
\text { by maintenance dose of } 0.3 \mathrm{mg} / \mathrm{kg} / \mathrm{day} \text { or using }\end{array}$ & $\begin{array}{l}\text { Cheilitis } \\
\text { Dry mouth and skin hair } \\
\text { loss }\end{array}$ \\
\hline $\begin{array}{l}\text { Tretinoin } \\
\text { Isotretenoin } \\
\text { Fenretinide } \\
\text { Etretinate }\end{array}$ & $\begin{array}{l}\text { They also reduce the CD4 cell } \\
\text { infiltrate. } \\
\text { Increases macrophage and thus } \\
\text { heals the OLP lesions. }\end{array}$ & $\begin{array}{l}0.1 \% \text { Tretanoin } 0.1 \% \text { in adhesive base for local } \\
\text { application twice daily. } \\
\text { Topical: } 0.1 \% \text { - Adhesive gel ( } 4 \text { times per day } \\
\text { for } 2 \text { months). } \\
\text { Isotretinoin } 0.1 \% \text { ( } 2 \text { times per day for } 2 \text { months) } \\
\text { Topical retinoid } 0.05 \% \text { in orabase. }\end{array}$ & $\begin{array}{l}\text { Itchiness } \\
\text { Headache } \\
\text { Elevation of serum liver } \\
\text { enzymes conjunctivitis. }\end{array}$ \\
\hline Dapsone & $\begin{array}{l}\text { Inhibits the release of chemotactic } \\
\text { factors for mast cells hence } \\
\text { reducing inflammation. }{ }^{26}\end{array}$ & $\begin{array}{l}50 \mathrm{mg} / \text { day } \\
\text { Hydrochloroquine 200-400 mg daily for } 6 \\
\text { months }\end{array}$ & $\begin{array}{l}\text { Hemolysis, G6PD } \\
\text { deficiency causing } \\
\text { hemolytic anemia or } \\
\text { methemoglobinemia, } \\
\text { hypersensitivity reaction. }{ }^{27}\end{array}$ \\
\hline Gresiofulvin & $\begin{array}{l}\text { Fungistaticaction } \\
\text { When administered gets deposited } \\
\text { on the keratin layer making it } \\
\text { durable. }{ }^{28}\end{array}$ & $500 \mathrm{mg} /$ day for 4 weeks & $\begin{array}{l}\text { Nausea, vomiting } \\
\text { diarrhea, headaches, } \\
\text { drowsiness, and fatigue, } \\
\text { ukopenia and neutropenia, } \\
\text { albuminuria, urticaria and } \\
\text { photosensitivity. }^{29}\end{array}$ \\
\hline Hyaluronic acid & $\begin{array}{l}\text { It enhances healing by forming a } \\
\text { protective coat in the mucosa and } \\
\text { thus keeping it hydrated. }\end{array}$ & $0.2 \% \mathrm{gel}$ & \\
\hline
\end{tabular}

Table 5: Nonpharmacological therapy used in oral lichen planus

\begin{tabular}{|c|c|c|c|}
\hline Therapy & Mechanism of action ${ }^{30}$ & Dose & Adverse effects \\
\hline $\begin{array}{l}\text { Puva therapy } \\
\text { 8-methoxy- } \\
\text { psoralen } \\
\text { (8-MOP) long } \\
\text { wave ultraviolet } \\
\text { light (PUVA). }\end{array}$ & $\begin{array}{l}\text { Psorolen obtained from } \\
\text { plants makes the skin } \\
\text { temporarily sensitive to UV } \\
\text { radiation. } \\
\text { PUVA causes } \\
\text { photoconjugation of } \\
\text { psoraleanto DNA and } \\
\text { subsequently causes } \\
\text { suppression of mitosis, } \\
\text { DNA synthesis, and cell } \\
\text { proliferation. } \\
\text { PUVA can effect specifically } \\
\text { lymphocytes or PMNL. } \\
\text { It causes immunologic } \\
\text { alterations hence } \\
\text { decreasing the levels of } \\
\text { lymphocytes. }\end{array}$ & $\begin{array}{l}\text { Dose: Methoxypsoralen is given orally, followed by } \\
\text { administration of } 2 \text { hours of UV radiation intraorally in } \\
\text { the affected sites. } \\
\text { Initial UVA dose was } 1.5-2 \mathrm{~J} / \mathrm{cm}^{2} \text { and was increased at } \\
\text { the first and third sessions of each week. } \\
\text { The maximum dose administered at the end of } \\
\text { treatment never exceeded } 7 \mathrm{~J} / \mathrm{cm}^{2} \text { in a single session. } \\
\text { Treated three times per week with an interval of } 48 \mathrm{~h} \\
\text { between each session. } \\
\text { Patient's tolerance to UVA permitted, the number of } \\
\text { weekly sessions was progressively increased to } 4 \text { and } \\
\text { subsequently } 5 .^{30}\end{array}$ & $\begin{array}{l}\text { Adverse effects: } \\
\text { nausea, dizziness, } \\
\text { photosensitivity for } \\
24 \text { hours. Epidermal } \\
\text { atrophy or pseudo- } \\
\text { parakeratosis. }{ }^{31}\end{array}$ \\
\hline
\end{tabular}


Oral Lichen Planus-A Brief Review on Treatment Modalities

Contd...

\begin{tabular}{|c|c|c|c|}
\hline Therapy & Mechanism of action ${ }^{30}$ & Dose & Adverse effects \\
\hline $\begin{array}{l}\text { Photodyanamic } \\
\text { therapy } \\
\text { contains } \\
\text { photosensitizer } \\
\text { along with } \\
\text { specific } \\
\text { harmless light. }\end{array}$ & $\begin{array}{l}\text { Immunomodulating activity } \\
\text { Photosensitizer is activated } \\
\text { by specific wavelength, } \\
\text { oxidizing the target cells by } \\
\text { producing singlet oxygen } \\
\text { and free radical, thus } \\
\text { destroying specific cells, } \\
\text { causing membrane lysis } \\
\text { and protein inactivation }{ }^{32}\end{array}$ & $\begin{array}{l}\text { Dose: Photosensitizers used: } \\
\text { Methylene blue, methyl } 5 \text { aminolevulinate, Chlorine-e- } 6 \\
\text { polyvinyl pyrrolidone. } \\
\text { Light source: Xenon arc lamp } 630 \pm 5 \mathrm{~nm} \text { and } 120 \mathrm{~J} / \\
\mathrm{cm}^{2} \\
\text { Diode laser- } 600-660 \mathrm{~nm} \text { and } 75 \mathrm{~J} / \mathrm{cm}^{2} \\
5 \% \text { solution of photosensitizer in aquous solution used } \\
\text { to rinse, } 10 \text { min later lesion exposed to light source. }\end{array}$ & $\begin{array}{l}\text { Pain and local } \\
\text { skin reactions } \\
\text { (LSRs), including } \\
\text { erythema, edema, } \\
\text { desquamation, or } \\
\text { pustule } \\
\text { Late changes: } \\
\text { bullous phemphigoid, } \\
\text { pigmentary changes } \\
\text { and carcinogenicity. } \\
\text { (4) }\end{array}$ \\
\hline $\begin{array}{l}\text { Low level laser } \\
\text { therapy }\end{array}$ & $\begin{array}{l}\text { Destroyes the keratinocytes } \\
\text { in superficial epithelium by } \\
\text { protein denaturation } \\
\text { Deep penetrated lasers } \\
\text { damage connective tissue } \\
\text { containing inflammatory } \\
\text { cells. } \\
\text { Modulated mast cells, } \\
\text { decreased prostaglandins } \\
\text { and increased the } \\
\text { production of basic growth } \\
\text { factors. }\end{array}$ & $\begin{array}{l}\text { The lasers used were } 904 \mathrm{~nm} \text { pulsed infrared laser } \\
\text { (four sessions weekly) and } 980 \mathrm{~nm} \text { gallium-aluminum- } \\
\text { arsenide diode laser. }{ }^{35,36}\end{array}$ & Erythema, soreness \\
\hline
\end{tabular}

Table 6: Natural alternatives used in oral lichen planus

\begin{tabular}{clll}
\hline Natural Component & Action & Dose \\
\hline & fat-soluble carotenoid & Antioxidant & Dose: 6-60 mg/day \\
& obtained from red fruits and vegetables and & Causes physical and chemical & For 2-32 weeks \\
of certain algae and fungi. Tomatoes and & quenching of free radicals. & \\
Lycopene & tomato-based products are the major sources & Replaces the lost antioxidants in & \\
& of lycopene. Other sources of lycopene are & case of oral lichen planus &
\end{tabular}
apricot, cranberry, grapes, pink grapefruit, guava, papaya, peaches, and watermelon. ${ }^{37}$ component of curcuma longa, i.e., turmeric

Anti-inflammatory. Immune modulatory activation of host macrophages and natural killer cells

Modulation of lymphocytes hence prevents basement membrane destruction ${ }^{39}$

Curcumin

Vitamins, inorganic compounds, essential and non-essential proteins

Aloe vera

Rich source of catechins:

Epicatechin (EC), Epicatechin-3-gallate (ECG),

Green tea Epigallocatechin (EGC) andEpigallocatechin-3gallate (EGCG)
Downregulates inflammatory

Antioxidant action by inhibiting free radical and nitric oxide ${ }^{40}$

Antibacterial,

Antifungal,

anti-inflammatory,

antioxidant,

antitumor,

and immune boosting properties

Anti-inflammatory and

chemopreventive.

immunomodulatory activity useful

for people with abnormal T cell

function $^{43}$ enzymes, cytokines.
$1 \mathrm{gm}$ for 2 weeks, then tapering it to 500 $\mathrm{mg}$ and $250 \mathrm{mg}$ every 2 weeks followed by 1 month topical application ${ }^{41}$

No side effects at high doses

Gel application thrice a day for 4-8 weeks ${ }^{42}$

\section{0 cups $(120 \mathrm{~mL} /$ cup) of green tea daily supplemented with green tea tablets have been recommended ${ }^{43}$}

\section{Contributing Etiological Factor in Oral Lichen Planus}

\section{Psychological Influence}

Oral lichen planus (OLP) was considered by researchers as a psychosomatic disorder whose occurrence was influ- enced by the conditions of stress, anxiety or depression or was considered as etiologic factors to OLP. ${ }^{44,45}$ A positive relation of oral lichen planus with the psychological status of an individual was noted. In 1998 studies had shown a greater incidence of OLP in people with a higher degree 
of anxiety, depression, and psychic disorders. ${ }^{46}$ On the contrary, the incidence of the lesion with their severity was also linked to the psychological condition of an individual. A long-term symptomatic lesion of lichen planus could lead to anxiety, tiredness, increased stress and cancerophobia in patients, which directly affects the everyday life of a person and also their attitude towards the disease. A prolonged disease state in an individual lead to the use of catastrophizing or strategies to cope with the intensity of pain, which in turn was seen affecting the lifestyle of the individual. ${ }^{47}$ In such cases exacerbating factors should be minimized, stress management, breathing exercise, and yoga should be practiced.

\section{REFERENCES}

1. PatilS, Khandelwal S, Sinha N, Kaswan S, Tipu FR. Treatment modalities of oral lichen planus: An update. J Oral Diagn 2012;1:47-52.

2. Andreasen JO. Oral lichen planus: I. A clinical evaluation of 115 cases. Oral Surgery, Oral Medicine, Oral Pathology. 1968 Jan 1;25(1):31-42.

3. McCreary CE, McCartan BE. Clinical management of oral lichen planus. Br J Oral MaxillofacSurg 1999;37:338-343

4. Jungell P. Oral lichen planus. A review. Int J Oral MaxillofacSurg 1991;20:129-135

5. Silverman S Jr. Lichen planus. CurrOpin Dent 1991;1:769-772

6. Scully C, el-Kom M. Lichen planus: review and update on pathogenesis. J Oral Pathol Med 1985;14:431-458.

7. Silverman S, Gorsky M, Lozada-Nur F: A prospective followup study of 570 patients with oral lichen planus: Persistence, remission, and malignant association. Oral Surg Oral Med Oral Patho 1985 Jul 1;60(1):30-34.

8. Kramer IR, Lucas RB, Pindborg JJ, Sobin LH. Defi nition of leukoplakia and related lesions: An aid to studies on oral precancer. Oral Surg Oral Med Oral Pathol 1978;46:518-539.

9. Maher HasanAghbari et al in 2017 Malignant transformation of oral lichen planus and oral lichenoid lesions- A meta analysis of 20095 patient data

10. Silverman S Jr. Oral lichen planus: A potentially premalignant lesion. J Oral MaxillofacSurg 2000;58:1286-1288

11. Carrozzo M, Gandolfo S. The management of oral lichenplanus. Oral Dis 1999;5:196-205.

12. Lozada-Nur F, Miranda C. Oral lichen planus: topical andsystemic therapy. Semin Cutan Med Surg 1997;16:295-300.

13. Jainkittivong A, Kuvatanasuchati J, Pipattanagovit P, Sinheng W. Candida in oral lichen planus patients undergoing topical steroid therapy. Oral Surgery, Oral Medicine, Oral Pathology, Oral Radiology, and Endodontology. 2007 Jul 1;104(1):61-66.

14. Werneck JT, Costa TD, Stibich CA, Leite CA, Dias EP, Silva Junior A. Oral lichen planus: study of 21 cases. Anais brasileiros de dermatologia. 2015 Jun;90(3):321-326.

15. Dreyer WP. The clinical manifestations of oral lichen planus. The Journal of the Dental Association of South Africa= Die Tydskrif van die Tandheelkundige Vereniging van SuidAfrika. 1983 Oct;38(10):619-624.

16. Sehgal VN, Abraham GJ, MALIK GB. Griseofulvin therapy in lichen planus: a double blind controlled trial. British Journal of Dermatology. 1972 Oct;87(4):383-385.
17. Lundström IM, Anneroth GB, Holmberg K. Candida in patients with oral lichen planus. International Journal of Oral and Maxillofacial Surgery. 1984 Jun 1;13(3):226-238.

18. Carbone M, Conrotto D, Carrozzo M, Broccoletti R, Gandolfo $\mathrm{S}$, Scully C. Topical corticosteroids in association with miconazole and chlorhexidine in the long term management of atrophic erosive oral lichen planus: a placebo controlled and comparative study between clobetasol and fluocinonide. Oral diseases. 1999 Jan;5(1):44-49.

19. Marable DR, Bowers LM, Stout TL, Stewart CM, Berg KM, Sankar V, et al. Oral candi-diasis following steroid therapy for oral lichen planus. Oral diseases. 2016 Mar;22(2):140-147.

20. Mostafa B, Zakaria M. Evaluation of Combined Topical Ozone and Steroid Therapy in Management of Oral Lichen Planus. Open access Macedonian journal of medical sciences. 2018 May 20;6(5):879-884.

21. Patil S, Khandelwal S, Sinha N, Kaswan S, Rahman F, Tipu S. Treatment modalities of oral lichen planus: an update. Journal of Oral Diagnosis. 2016;1(1):01:e3

22. Epstein JB, Truelove EL. Topical cyclosporine in a bioadhesive for treatment of oral lichenoid mucosal reactions: an open label clinical trial. Oral Surgery, Oral Medicine, Oral Pathology, Oral Radiology, and Endodontology. 1996 Nov 1;82(5):532-536.

23. Eisen D, Carrozzo M, Bagan Sebastian JV, Thongprasom K. Number V Oral lichen planus: clinical features and management. Oral diseases. 2005 Nov;11(6):338-349.

24. Thongprasom K, Chaimusig M, Korkij W, Sererat T, Luang jarmekorn $\mathrm{L}$, et al. A randomized controlled trial to compare topical cyclosporin with triamcinolone ace-tonide for the treatment of oral lichen planus. Journal of oral pathology \& medicine. 2007 Mar;36(3):142-146.

25. Olejarz W, Bryk D, Zapolska-Downar D. Mycophenolate Mofetil A New Atheropreventive Drug?. Acta poloniae pharmaceutica. 2014 May;71(3):353-361.

26. Wee JS, Shirlaw PJ, Challacombe SJ, Setterfield JF. Efficacy of mycophenolate mofetil in severe mucocutaneous lichen planus: a retrospective review of 10 patients. British Journal of Dermatology. 2012 Jul;167(1):36-43.

27. Beck HI, Brandrup F. Treatment of erosive lichen planus with dapsone. Acta dermato-venereologica. 1986;66(4):366-367.

28. Graham Jr WR. Adverse effects of dapsone. International journal of dermatology. 1975 Sep;14(7):494-500

29. Aufdemorte TB, De Villez RL, Gieseker DR. Griseofulvin in the treatment of three cases of oral erosive lichen planus. Oral Surgery, Oral Medicine, Oral Pathology. 1983 May 1;55(5):459462.

30. Honigsmann H, Wolff K, Fitzptrik TB. Oral photochemotherapy with psorolean and UVA Principles and practice in Dermatology in Genral Medicine. 3rd edition 1987;1533-1558.

31. Ortonne JP, Thivolet J, Sannwald C. Oral photochemotherapy in the treatment of lichen planus (LP). Clinical results, histological and ultrastructural observations. Br J Dermatol. 1978 Jul;99(1):77-88.

32. Lavanya N, Jayanthi P, Rao UK, Ranganathan K. Oral lichen planus: An update on pathogenesis and treatment. Journal of oral and maxillofacial pathology: JOMFP. 2011 May;15(2):127.

33. Jori G, Fabris C, Soncin M, Ferro S, Coppellotti O, Dei D, Fantetti L. et al. Photodynamic therapy in the treatment of microbial infections: basic principles and perspective applications. Lasers Surg Med. 2006;38(5):468-481. 
34. Diana Mostafa, Bassel Tarakji. Photodynamic Therapy in Treatment of Oral Lichen Planus. J Clin Med Res. 2015 Jun;7(6):393-399.

35. Borgia F, Giuffrida R, Caradonna E, Vaccaro M, Guarneri F, Cannavò S. Early and late onset side effects of photodynamic therapy. Biomedicines. 2018 Mar;6(1):12.

36. Jajarm HH, Falaki F, Mahdavi O. A comparative pilot study of low intensity laser versus topical corticosteroids in the treatment of erosive-atrophic oral lichen planus. Photomedicine and laser surgery. 2011 Jun 1;29(6):421-425.

37. Clinton SK. Lycopene: chemistry, biology, and implications for human health and disease. Nutrition reviews. 1998 Feb 1;56(2):35-51.

38. Saawarn N, Shashikanth MC, Saawarn S, Jirge V, Chaitanya NC, Pinakapani R. Lycopene in the management of oral lichen planus: a placebo-controlled study. Indian Journal of Dental Research. 2011 Sep 1;22(5):639-643.

39. Keshari D, Patil K, Mahima VG. Efficacy of topical curcumin in the management of oral lichen planus: A randomized controlled-trial. J Adv Clin Res Insights. 2015;2:197203.

40. Amirchaghmaghi M, Pakfetrat A, Delavarian Z, Ghalavani $\mathrm{H}$, Ghazi A. Evaluation of the Efficacy of Curcumin in the Treatment of Oral Lichen Planus: A Randomized Controlled Trial. Journal of clinical and diagnostic research: JCDR. 2016 May;10(5):ZC134-ZC137.
41. Prasad S, Solanki S, Chinmaya BR, Tandon S, Ashwini B. The magic of herbal curcumin therapy in recurrent oral lichen planus. Am J Ethnomed. 2014;1:96-101.

42. Reddy RL, Reddy RS, Ramesh T, Singh TR, Swapna LA, Laxmi NV. Randomized trial of aloe vera gel vs triamcinolone acetonide ointment in the treatment of oral lichen planus. Quintessence international. 2012 Oct 1;43(9).

43. Zhang J, Zhou G. Green tea consumption: an alternative approach to managing oral lichen planus. Inflammation Research. 2012 Jun 1;61(6):535-539.

44. Preda EG, Pasetti P, Caggiula S, Nidoli G, Boggio E, Azzi R. Oral pathology of pscyhosomatic origin. Review of the literature. Dental Cadmos. 1990 Jan;58(1):66-72.

45. Akay A, Pekcanlar A, Bozdag KE, Altintas L, Karaman A. Assessment of depression in subjects with psoriasis vulgaris and lichen planus. Journal of the European Academy of Derma-tology and Venereology. 2002 Jul;16(4):347-352.

46. Rojo-Moreno J, Bagán J, Rojo-Moreno J, Donat JS, Milián MA, Jiménez Y. Psychologic factors and oral lichen planus: a psychometric evaluation of 100 cases. Oral surgery, oral medicine, oral pathology, oral radiology, and endodontology. $1998 \mathrm{Dec}$ 1;86(6):687-691.

47. Radwan-Oczko M, Zwyrtek E, Owczarek JE, Szcze niak D. Psychopathological profile and quality of life of patients with oral lichen planus. Journal of Applied Oral Science. 2018; 26. 